\title{
Tropical Journal of Pathology and Microbiology

\section{A study of wound infections and its antibiogram in surgical intensive care unit of a tertiary care hospital}

\author{
Bhumbla U. ${ }^{1 *}$, Muneer Ahmed S. ${ }^{2}$, Raj Mathur D. ${ }^{3}$, Dalal A. ${ }^{4}$ \\ DOI: https://doi.org/10.17511/jopm.2019.i07.10 \\ 1* Upasana Bhumbla, Assistant Professor, Department of Microbiology, Geetanjali Medical College and Hospital, Udaipur, Rajasthan, India. \\ 2 Safaa Muneer Ahmed, Consultant Microbiologist, Hyderabad, Telangana, India. \\ 3 Dinesh Raj Mathur, Professor, Department of Microbiology, Shadan Institute of Medical Sciences, Hyderabad, Telangana, India. \\ ${ }^{4}$ A.S. Dalal, Professor and Head of Department, Department of Microbiology, Geetanjali Medical College and Hospital, Udaipur, Rajasthan, \\ India.
}

Background: Wound infections can be caused through two major sources: exogenous and endogenous bacteria. The probability of wound infection largely depends on the patients systemic host defenses, local wound conditions and microbial burden. Despite modern surgical techniques and the use of antibiotic prophylaxis, Surgical Site Infection (SSI) is one of the most common complications encountered in surgery. SSI places a significant burden on both the patient and health system. SSI is thus a major cause of morbidity, prolonged hospital stay and increased health costs. Objective of this study was to identify and isolate various bacteria from wound infections in a surgical intensive care unit and to study their antibiogram. Methods: Two wound swabs were collected from the wound and from a drop of aspirate, smear was made on clean glass slide and Gram staining was done for direct microscopic examination under oil immersion 100X objective to know various morphological types of bacteria and presence or absence of inflammatory cells. Second swab/drop of aspirate was used for culture by inoculating it on routine media like Blood Agar, Nutrient Agar and Mac Conkeys agar, incubated at $37^{\circ} \mathrm{C}$ for 24 hours aerobically. Result: Out of 238 pus samples, $209(88.6 \%)$ were culture positive for bacterial growth and no growth was observed in $29(12.4 \%$ ) cases. Out of 209 bacterial culture positive cases, 201 were monobacterial and 8 were poly bacterial. Out of 201 bacterial isolates; S. aureus $(56 / 26.6)$ was the commonest followed by $P$. aeruginosa $(47 / 22.4 \%)$. Conclusion: The study concludes that variety of aerobic bacteria is responsible for wound infection with predominance of Staphylococcus aureus followed by Pseudomonas aeruginosa

Keywords: Staphylococcus aureus, Pseudomonas aeruginosa, Monobacterial

Corresponding Author

Upasana Bhumbla, Assistant Professor, Department of Microbiology, Geetanjali Medical College and Hospital, Udaipur, Rajasthan, India. Email: ucupasana124@gmail.com
How to Cite this Article

Bhumbla U, Muneer Ahmed S, Mathur DR, Dalal AS. A study of wound infections and its antibiogram in surgical intensive care unit of a tertiary care hospital. Trop J Pathol Microbiol. 2019;5(7):473-478. Available From https://pathology.medresearch.in/index.php/jopm/ar ticle/view/290
To Browse

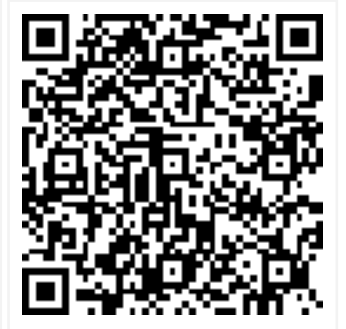

Manuscript Received 2019-07-10

Conflict of Interest No
Review Round 1 2019-07-20

Funding
Review Round 3

Review Round

Ethical Approval Yes
Plagiarism X-checker $7 \%$
Accepted 2019-07-31

(C) 2019 by Upasana Bhumbla, Safaa Muneer Ahmed, Dinesh Raj Mathur, A.S. Dalal and Published by Siddharth Health Research and Social Welfare Society. This is an Open Access article licensed under a Creative Commons Attribution 4.0 Internationa License https://creativecommons.org/licenses/by/4.0/ unported [CC BY 4.0] 


\section{Introduction}

Infection is defined as invasion and multiplication of micro organisms in the body tissues, which may be clinically in apparent or result in local cellular injury because of competitive metabolism, toxins, intracellular replication or antigen antibody response [1]. This series of events lead to progressive tissue destruction and eventual host demise if left unchecked. The infection process begins with a disruption of the host mechanical barriers to micro organisms, the availability of microorganisms and colonization [2]. Wound infections can be caused through two major sources: exogenous and endogenous bacteria. The probability of wound infection largely depends on the patients systemic host defenses, local wound conditions and microbial burden $[3,4]$. Despite modern surgical techniques and the use of antibiotic prophylaxis, Surgical Site Infection (SSI) is one of the most common complications encountered in surgery [5]. SSI places a significant burden on both the patient and health system. SSI is thus a major cause of morbidity, prolonged hospital stay and increased health costs [6].

Skin and soft tissue infections (SSTIs) may also contribute to longer hospital stays increase the cost of medical care and play an important role in development of antimicrobial drug resistance. Common examples of SSIs includes cellulitis, abscesses, impetigo, folliculitis, furuncle, carbuncle, necrotizing fasciitis, diabetic foot infections and surgical site infections. Complicated SSI may prove fatal and require hospitalization, intravenous antibiotics or surgery. An SSI is classified as complicated if the infection has spread to the deeper soft tissue, if surgical intervention is necessary or if the patient has co-morbid conditions Hence, this study could play a significant role in the early recognition of the Problem and hence, there is need for early intervention for better management of wound infections.

\section{Material and Methods}

Duration \& Setting: This study was done in a tertiary care hospital for a period of one year from Jan 2016-Dec 2016.

Ethical clearance: Ethical clearance from the Institutional Ethical committee was obtained.

Sample size: Two hundred \& thirty eight cases of pussamples were taken.
Isolation and identification of aerobic bacterial pathogens was done, from various departments like Surgery, Gynecology \& Orthopedics.

Data collection: Wound swabs were collected as per the procedure described below.

Procedure: Two wound swabs were collected from the wound and from a drop of aspirate, smear was made on clean glass slide and Gram staining was done for direct microscopic examination under oil immersion 100X objective to know various morphological types of bacteria and presence or absence of inflammatory cells. Second swab/drop of aspirate was used for culture by inoculating it on routine media like Blood Agar, Nutrient Agar and MacConkeys agar, incubated at $37^{\circ} \mathrm{C}$ for 24 hoursaerobically [7-9].

The plates were examined the next day for growth. Plates not showing any growth were further incubated at $37^{\circ} \mathrm{C}$ aerobically for another $24 \mathrm{hrs}$. Plates not showing any growth after 48 hrs on aerobic incubation were considered to be lacking aerobic bacterial pathogens. Smears were made, stained by Gram stain and examined under oil immersion microscope 100X objective.

Antibiotic sensitivity testing was performed on Mueller Hinton Agar according to CLSI guidelines. MRSA was detected using Cefoxitin (30ug) discand ESBL production in Gram negative bacteria was detected by using Potentiated Disc Diffusion Test (PDT)[8-10].

Inclusion criteria: All the swabs for aerobic bacterial pus culture were obtained

Exclusion criteria: Patients already on antibiotics were excluded from the study

\section{Results}

Two hundred \& thirty eight cases of pus samples were taken. Aerobic bacterial pathogens were isolated and identified from various departments like Surgery, Gynecology and Orthopedics. Surgical wound swabs were $139(58.4 \%)$ and Non Surgical wound swabs were $99(41.5 \%)$ in number. Out of 99 Non-surgical wounds, 69(69.6\%) were soft tissue infections wound and burn wounds, and 30(30.3\%) were traumatic wounds. Out of 139 surgical wounds, $86(61.8 \%)$ were post-operative wounds and $43(30.9 \%)$ were various other surgical site wounds. 
Table-1: Distribution pattern of bacterial isolates $(n=238)$.

\begin{tabular}{|l|l|}
\hline \multicolumn{1}{|c|}{ Organisms } & \multicolumn{1}{c|}{ Total No. of cases } \\
\hline Staphylococcus aureus & 52 \\
\hline Pseudomonas aeruginosa & 41 \\
\hline Escherichia coli & 26 \\
\hline Klebsiella pneumoniae & 25 \\
\hline Proteus mirabilis & 17 \\
\hline Acinetobacter spp. & 11 \\
\hline Coagulase negative Staphylococci & 11 \\
\hline Enterococcus fecalis & 10 \\
\hline Citrobacter freundii & 08 \\
\hline P.aeruginosa + S.aureus & 03 \\
\hline P. aeruginosa + K.pneumoniae & 03 \\
\hline S. aureus + P. mirabilis & 01 \\
\hline K.pneumoniae + P. mirabilis & 01 \\
\hline No growth & 29 \\
\hline
\end{tabular}

Pus discharge was collected from 238 patients were identified, out of which $167(70.1 \%)$ were males and $71(29.9 \%)$ were females.
Cases of pus discharge came mainly from rural areas $(199 / 83.61 \%)$ as compared to urban areas (39/16.38\%).

Bacterial isolates: Out of 238 pus samples, $209(88.6 \%)$ were culture positive for bacterial growth and no growth was observed in $29(11.4 \%)$ cases as shown in Table 1. Out of 209 bacterial culture positive cases, 201 were monobacterial and 8 were poly bacterial. Out of 209 bacterial isolates; S. aureus $(56 / 26.6 \%)$ was the commonest followed by $P$. aeruginosa $(47 / 22.4 \%)$. The prevalence of monomicrobial isolates from various wound infections is depicted in table 2, wherein Staphylococcus aureus was the predominant organism when samples were collected from post operative wounds, burns, traumatic wounds and soft tissue infections.

Table-2: Monomicrobial isolates in various wound infections.

\begin{tabular}{|l|l|l|l|l|l|l|l|l|l|}
\hline \multicolumn{1}{|c}{ Types of wounds } & S.aureus & P.aeruginosa & E.coli & K.pneumoniae & P.mirabilis & Acinetobacter spp. & CoNS & E.fecalis & C.freundii \\
\hline Post operative wounds & 12 & 6 & 17 & 17 & 8 & 7 & 6 & 2 & 1 \\
\hline Burns & 5 & 31 & 3 & - & 4 & - & 2 & 1 & 5 \\
\hline Traumatic & 16 & 4 & 4 & 1 & 3 & 2 & 2 & 1 & 1 \\
\hline Soft tissue infections & 19 & & 2 & 7 & 2 & 2 & 1 & 6 & 1 \\
\hline Total & 52 & 41 & 26 & 25 & 17 & 11 & 11 & 10 & 08 \\
\hline & $25.8 \%$ & $20.3 \%$ & $12.9 \%$ & $12.4 \%$ & $8.4 \%$ & $5.4 \%$ & $5.4 \%$ & $4.9 \%$ & $3.9 \%$ \\
\hline
\end{tabular}

Antibacterial susceptibility profile: Gram positive bacteria showed maximum susceptibility to Vancomycin whereas gram negative isolates showed its maximum susceptibility to Meropenem and Amikacin. $P$. aeruginosa isolates showed maximum susceptibility to Doripenem and Piperacillin tazobactum. $44.2 \%$ of S.aureus isolateswere MRSA and $56 \%$ of Gram negative isolates were ESBL producers as shown in Table 3.

Table-3: Antibiotic sensitivity
bacterial isolates.
\begin{tabular}{|l|l|l|l|}
\hline Antibiotics & $\begin{array}{r}\text { Gram positive } \\
\text { isolates } \mathrm{n}=\mathbf{7 3}\end{array}$ & $\begin{array}{l}\text { Gram negative } \\
\text { isolates } \mathbf{n}=\mathbf{8 7}\end{array}$ & $\begin{array}{l}\text { Pseudomonas } \\
\text { isolates } \mathbf{n}=\mathbf{4 1}\end{array}$ \\
\hline $\begin{array}{l}\text { Vancomycin } \\
\text { (VA) }\end{array}$ & $100 \%$ & & \\
\hline $\begin{array}{l}\text { Clindamycin } \\
\text { (CD) }\end{array}$ & $26.5 \%$ & - & \\
\hline $\begin{array}{l}\text { Linezolid } \\
\text { (LZ) }\end{array}$ & $80.5 \%$ & - & \\
\hline
\end{tabular}

\begin{tabular}{|l|l|l|l|}
\hline Erythromycin (E) & $28.9 \%$ & - & \\
\hline Ampicillin (AMP) & $11.8 \%$ & - & \\
\hline Amoxyclav (AMC) & $32.9 \%$ & - & \\
\hline Ceftriaxone (CTR) & $53.5 \%$ & $55.6 \%$ & $61 \%$ \\
\hline Cefoxitin (CX) & $55.8 \%$ & - & \\
\hline Cefotaxime (CTX) & - & $44.4 \%$ & \\
\hline Ceftazidime (CAZ) & - & $38.9 \%$ & $61.1 \%$ \\
\hline Gentamicin (GEN) & $71.2 \%$ & $38.9 \%$ & $33.3 \%$ \\
\hline Amikacin (AK) & $82.4 \%$ & $72.2 \%$ & $69.4 \%$ \\
\hline Imipenem (IPM) & - & $74.4 \%$ & $86.1 \%$ \\
\hline Meropenem & - & $87.1 \%$ & $86.7 \%$ \\
\hline Doripenem & - & $90.6 \%$ & $91.4 \%$ \\
\hline Piperacillin + Tazobactum (TZP) & - & $66.7 \%$ & $90.7 \%$ \\
\hline Cefopodoxime (CPZ) & - & $50 \%$ & - \\
\hline Ciprofloxacin (CIP) & - & $33.3 \%$ & $36.1 \%$ \\
\hline Netlimicin (NET) & - & - & $44.4 \%$ \\
\hline MRSA & - & - & \\
\hline ESBL producers & $56 \%$ & \\
\hline
\end{tabular}




\section{Discussion}

In the present study an attempt was made to study the bacteriological profile of wound infections and antimicrobial susceptibility pattern of the isolates. In this study along with the identification of aerobic bacterial organisms, changing pattern of antibiotic sensitivity with special reference to Methicillin Resistant Staphylococcus aureus (MRSA) and Extended Spectrum of Beta lactams (ESBLs) were alsoidentified.

It was observed that the commonest age group affected is $21-40$ years which is correlated with the studies done by Shute Malik et al [11] and Dr. Zarrin Afroz et al [12]. Males (70.1\%) were affected more than females $(29.9 \%)$. This study was correlated with Ramesh Rao et al [15] which found males $(60 \%)$ more affected than females, $N$. Sowmya et al [14] $66.6 \%$ and Shruti Malik et al [11] $51.9 \%$ also showed the predominance of males over females probably because of their more exposure to life.

Monomicrobial etiology was more common $96.1 \%$, than polymicrobial $3.8 \%$. This study is correlated with N. Soumya et al [14] $91.7 \%$ and Mehta V.J. et al [15] $70.4 \%$ wherein the monomicrobial etiology was more common than polymicrobial which may be due to the prior use of antibiotics.

In the present study Staphylococcus aureus 26.6\% was the predominant organism followed by Pseudomonas aeruginosa 22.4\%, Escherichia coli $12.9 \%$, Klebsiella pneumoniae $12.4 \%$, Proteus mirabilis $8.4 \%$ and CONS $5.4 \%$. Staphylococcus aureus $(26.6 \%)$ was the most predominant isolate which correlated with the other studies done Shruti Malik (30.1\%), Mehta V.J. (38.3\%), Ramesh Rao (27.8\%) and Dr. Pravin (48.4\%) [13-16].

Second most predominant organism in the present study was Pseudomonas aeruginosa $22.4 \%$ which correlated with the studies of Gayathree Naik $(20 \%)$, Shruti Malik (17.8\%), Mehta V.J (21.3\%), Ramesh Rao (18.5\%) and Dr. Pravin (17.52\%) [1115]. In the present study, polymicrobial 8 cases included combination of Pseudomonas aeruginosa with Staphylococcus aureus (37.5\%) which correlates with the study of Anbumani et al. Other polymicrobials included Pseudononas aeruginosa with Klebsiella pneumonia accounting for $37.5 \%$ cases, Klebsiella pneumonia with Proteus mirabilis $12.5 \%$ and Staphylococcus aureus with Proteus mirabilis $12.5 \%$ case. Out of 52 Staphylococus
Aureus isolates, $23(44.3 \%)$ were MRSA producers and remaining 29 (55.7\%) were MSSA producers. The present study correlates with the study of Rajaduraipandi et al [19] with 31\%, Anupurba et al [18] with $32 \%$ and $N$. Soumya et al [14] with $27.5 \%$, as MRSA producers. Among 77 Enterobactericeae isolates, $56 \%$ were ESBLproducers and $44 \%$ were Non-ESBL producers which correlated with the studies done by Mehta V.J [15] with $44.6 \%$ as ESBL producers.

In the present study, Vancomycin (100\%) was the most sensitive antibiotic among all gram positive isolates which was correlated with the studies of Amrita Shriyan et al [21], Shahnooshi Javed et al [22] and Jeena Amatya et al [23]. Amikacin was the second most sensitive antibiotic to many gram positive as well as gram negative isolates accounting for $82.4 \%$, which is correlated with the study of Amrita Shriyan et al [21] 95\% and Shruti Malik et al [11] 90\%. Meropenem was the most sensitive drug among gram negative isolates accounting for $87.1 \%$ which was correlating with the study of Shruti Malik et al [11], Amrita Shriyan et al [21] and Ramesh Rao et al [13]. Limitation of this study was that only bacterial samples were isolated where in fungal isolates could also be isolated for better understanding if surgical infections.

\section{Conclusion}

Wound infections are one of the most common hospital acquired infections, and are an important cause of morbidity \& account for $70-80 \%$ mortality. Development of such infections represent delayed healing, cause anxiety \& discomfort for patient, longer stays at hospitals \& add to cost of healthcare services significantly. This study was carried out to determine the antibacterial susceptibility of bacteria isolated from wound infections as well as update the clinicians in the various antimicrobial alternatives available in the treatment of wound infections, thus helping to reduce the burden of infection on patients and in long term, it may reduce the cost of treatment.

The study concludes that variety of aerobic bacteria is responsible for wound infection with predominance of Staphylococcus aureus followed by Pseudomonas aeruginosa. Also there were mixed infections with different bacteria. Antibiotic sensitivity pattern of the study revealed that Amikacin was the most sensitive drug among both gram positive and gram negative isolates. 
Meropenem was the most sensitive drug among all gram negative isolates and Vancomycin was the most sensitive drug among gram positive isolates. This study shows that the organisms are becoming resistant to commonly used antibiotics and also developing resistance to newer antibiotics.

\section{What the study adds to the existing knowledge?}

Nowadays automated methods of identification of the pathogen and antibiotic sensitivity are available which aids in quick results, thus reducing the time of treatment and helping the patients. More comprehensive studies are required from time to time to define the magnitude of problem \& produce data for policy decision on optimal intervention modalities. Vital use for formulation of antibiotic policy and implementation of antimicrobal stewardship program-mmes is need of the hour. Hospital must have an active antibiotic stewardship programme implemented. Further based on the antibiogram of hospital, antibiotic policy should be framed and followed. Such a treatment policy if followed will lead to reduction in mortality, morbidity $\&$ health care cost associated with wound infections.

\section{Author's contributions}

All the authors contributed equally in the study design, analysis and manuscript preparation

\section{Reference}

01. McGeer A, Campbell B, Emori TG, Hierholzer WJ, Jackson MM, Nicolle LE, et al. Definitions of infection for surveillance in long-term care facilities. Am J Infect Control. 1991;19(1)1-7. [Crossref][PubMed] [Google Scholar]

02. Patricia Tille. Text book of Diagnostic Microbiology, Bailey and Scott's. Thirteenth Edition. 961-970. [Crossref][PubMed][Google Scholar]

03. Lauwers S, de Smet F. Surgical site infections. Acta Clin Belg. 1998;53(5)303-10. [Crossref] [PubMed][Google Scholar]

04. Culbertson Wr, Altemeier Wa, Gonzalez LI, Hill Eo. Studies on the epidemiology of postoperative infection of clean operative wounds. Ann Surg. 1961;154;599-610. doi: 10.1097/00000658196110000-00010 [Crossref][PubMed][Google Scholar]
05. M Olson, MO' Connor, ML Schwartz. Surgical wound infections of 5 year prospective study of 20, 193 wounds at Minneapolis Va Medical Centre. Ann Surg. 1984;199(3)253-259. [Crossref][PubMed] [Google Scholar]

06. Dellinger EP in Sabiston DC, Lyerly K. (Eds) Textbook of Surgery, 18th Edn. WB Saunders Company, Philladilphia. PP-264-280. [Crossref] [PubMed][Google Scholar]

07. Forber BA, Salm DF. Weissfiled Diagnostic Microbiology, In Bailey and Scott's, 13th edition. Missiouri, Mosby Elsevier. 1998. [Crossref][PubMed] [Google Scholar]

08. Washington CW, Stephen DA, William M, Elmer WK et al. In Koneman's Colour atlas and text book of microbiology. 6th ed; Philadelphia- Lippincotts Williams and Walkins. 2006; 68-74. [Crossref] [PubMed][Google Scholar]

09. Clinical and Laboratory Standard Institute. Perfor-mance Standards for antimicrobial susceptibility testing. twenty third informational supplement. M100-S24;2017(34)50-57. [Crossref] [PubMed][Google Scholar]

10. Miles RS, Anyes SGB. Laboratory Control of antimicrobial therapy, in General Colle J, Barrie P, Andrew GF, Anthony $S$, editors. Mackie and Mc Cartney Practical Medical Microbiology; 14th edition; New Delhi. 2007;151-178. [Crossref][PubMed] [Google Scholar]

11. Malik S, Gupta A, Singh KP, Agarwal J, Singh M. Antibiogram of aerobic bacterial isolates from postoperative wound infections at a tertiary care hospital in India. J Infect Dis Antimicrob Agents. 2011;28(1)45-51. [Crossref][PubMed][Google Scholar]

12. Afroz Z, Metri CB, Jyoti P. Bacteriological Profile and Antimicrobial Susceptibility Pattern of Skin and Soft Tissue Infections among Gram Negative Bacilli in a Tertiary Care Hospital of South India. J Pharm Sci Res. 2015;7(7)397-400. [Crossref][PubMed] [Google Scholar]

13. Rao R, Sumathi S, Anuradha K, Venkatesh D, Krishna S. Bacteriology of postoperative wound infections. Int J Pharm Biomed Res. 2013;4(2)72-6. [Crossref][PubMed][Google Scholar]

14. Sowmya N, Savitha $S$, Mallure $S$, Mohanakrishnan K, Sumathi G, Arumugam P. A two year study of spectrum of bacterial isolates from 
Wound infections by aerobic culture and their antibiotic pattern in a tertiary care center. Int J Curr Microbiol App Sci. 2014;3(8)292-5. [Crossref] [PubMed][Google Scholar]

15. Mehta VJ, Pandya JM, Mehta SJ. Surveillance of Post Operative wound infections in a Teaching Hospital, Gujarat. Int J Res Med. 2013;2(4)77-9. [Crossref][PubMed][Google Scholar]

16. Naik G, Deshpande S. A study on surgical site infections caused by Staphylococcus aureus with a special search for methicillin-resistant isolates. J Clin Diagn Res. 2011;5(3)502-8. [Crossref] [PubMed][Google Scholar]

17. Suryawanshi P, Khan AQ, Saiyyad Altaf G, Patil A. Analysis of Organisms Found at Incision Site Intra-Operatively and its Implications with PostOperative infections. Int J Sci Res Pub. 2014;67. [Crossref][PubMed][Google Scholar]

18. N Anbumani, J Kalyani, M Mallika. Prevalence of methicillin resistant Staphylococcus aureus in a tertiary referral hospital in Chennai, South India. Ind J Pract Doc. 2006;48(4)191-195. [Crossref] [PubMed][Google Scholar]

19. Rajaduraipandi K, Mani KR, Panneerselvam K, Mani M, Bhaskar M, Manikandan P. Prevalence and antimicrobial susceptibility pattern of methicillin resistant Staphylococcus aureus- a multicentre study. Indian J Med Microbiol. 2006;24(1)34-8. doi: 10.4103/0255-0857.19892 [Crossref][PubMed] [Google Scholar]
20. Anupurba S, Sen MR, Nath G, Sharma BM, Gulati AK, Mohapatra TM. Prevalence of methicillin resistant Staphylococcus aureus in a tertiary referral hospital in eastern Uttar Pradesh. Indian J Med Microbiol. 2003;21(1)49-51. [Crossref][PubMed] [Google Scholar]

21. Shriyan A, Sheetal R, Nayak N. Aerobic microorganisms in Post-Operative wound infections and their Antimicrobial suspceptibility Patterns. J Clinic Diagnos Res. 2010;4;3392-3396. [Crossref] [PubMed][Google Scholar]

22. Javed FS, Reazvanian M, Kumar S, Norouzi H. Microbiological study of diabetic foot ulcer in an Indian Tertiary Care Hospital. Int $\mathrm{J}$ Life Sci and Review. 2015;1(2)65-70. [Crossref][PubMed] [Google Scholar]

23. Jeena Amatya, Manish Rijal and Reena Baidya. Bacteriological study of the Post Operative wound samples and antibiotic susceptibility pattern of the isolates in B\&B Hospital Lalitpur Nepal. JSM Microbiology. 2015;3(1)1019. [Crossref][PubMed] [Google Scholar]

24. Rai S, Yadav UN, Pant ND, Yakha JK, Tripathi PP, Poudel A, et al. Bacteriological Profile and Antimicrobial Susceptibility Patterns of Bacteria Isolated from Pus/Wound Swab Samples from Children Attending a Tertiary Care Hospital in Kathmandu, Nepal. Int J Microbiol. 2017;2529085. doi: 10. 1155/2017/2529085 [Crossref][PubMed] [Google Scholar] 